UDC 37.014.6

DOI: 10.12958/EPS.1(162).Liakhotska_L_L

\title{
Liakhotska L. L.
}

\section{ADVANCED TRAINING OF EDUCATION EXECUTIVES: DISTANCE LEARNING TECHNIQUES}

The first quarter of the third millennium is characterized by the search for new trends in the development of the civilization, the common feature of which is, among others, a new scale and rate of spread of scientific knowledge in social practice.

Science and its technological application is the main source of economic advance, a core advantage in competitive economic activity and military confrontation. On the other side, the developing opportunities provided by intellectual, information, and communication revolution appeared to be conducive to the approval of a new vector of the development of the civilization in its focus on knowledge-based society.

Obviously, the idea of the formation of the knowledge-based society can be successfully realized only by the creation of entirely new systems that produce scientific knowledge. Under such conditions, the lack of knowledge, gaps in education, inability of the society to produce and implement social sciences and humanities knowledge to the degree required by the times make it uncompetitive on the world arena and relegate it to the background of the development of the civilization.

Informatization of both the educational system in general and advanced training system in particular is a transparent, universal direction of the educational system innovative development, the resources of which have not been properly used yet.

The theoretical basis of this research is the works of native and foreign scholars, devoted to: the content and structure of pedagogical activity (I. A. Ziaziun, N. V. Kuzmina, V. O. Onishchuk, I. P. Pidlasyi, V. O. Slastionin), theory and practice of distance learning (M. Yu. Bukharkina, V. H. Domrachev, M. V. Moiseieva, Ye. S. Polat, S. O. Shchennikov); 
education and information society (John Tiffin, Lalita Rajasingham, Don Tapscott, Karl Popper, Michael Fullan), pedagogical and methodical foundations of the application of information and communication technology in teaching (O. O. Andreiev, H. Beshmen, Ye. F. Vinnychenko, Yu. Horoshko, Yu. O. Doroshenko, M. I. Zhaldak, T. H. Kramarenko, V. M. Kukharenko, V. V. Lapinskyi， V. M. Madzigon, G. Marshall, P. I. Obraztsov, Ye. S. Polat, S. A. Rakov, I. V. Robert, V. V. Soldatkin, A. I. Uman, C. Hovland); designing of digital educational resources on the basis of pedagogical design (V.P. Bespalko, Ye. I. Mashbits， V. M. Podkovyrova， V. Ye. Radionov， O. Yu. Uvarov), knowledge management (Yu. P. Adler, Thomas M. Koulopoulos, B. Z. Milner, I. Nonaka, L. N. Ruliiene, H. Takeuchi, N. V. Tikhomirova, Carl Frappaolo, Ye. A. Chernykh); scientific ensuring of advance distance learning, organizational and pedagogical foundations of distance learning in advanced training of education executives and teaching staff (V. Yu. Bykov, V. O. Gravit, L. O. Leshchenko, M. I. Mikhalchenko, V. V. Oliinyk, O. M. Samoiilenko, S. O. Sysoieva, P. M. Talanchuk).

Accelerated development of information and communication technology and expansion of new methodological educational systems create conditions for an unlimited (full, immediate, precise, whenever and wherever, effortless, etc.) access of every subject of education to digital teaching resources. Thus, the introduction of distance learning technology to advanced training of education executives becomes widespread. The relevance of the afore-mentioned is confirmed by an active use of email (as the simplest distance learning tool), wide range of the Internet social services, network education tools, systems of educational websites of "cloud computing" technology, which change the formation of the information culture of listeners and development of professional expertise.

The informatization of professional pedagogical education at the modern stage of the development of society is directed at the training quality improvement, achievement of better results in education using teaching materials based on the information and communication technology. This approach presents education as the process of information interaction between the source of information and its consumer.

Training of education executives under the conditions of the informatization of advanced training presupposes the development and adoption of new educational models with 
the use of information and communication technology. Readiness of the director of an educational institution to use this technology is an extremely important condition for the shift to personality-oriented education that meets requirements of information society development.

The change of the educational paradigm in general, and postgraduate pedagogical education in particular, causes the changes of the forms and means of education, relations between the instructor and the student. The modernization of Ukrainian education requires the revision of the content of education executives training to teach them to use information technology, as well as the development of new approaches to the designing of digital teaching materials. This initiates the preparation of instructors for postgraduate pedagogical education to use during advanced training the knowledge management methods based on pedagogical design. Thus, the process of the formation of their professional and pedagogical culture and competence is in progress.

The purpose of this article is to define the methodology of using e-learning technique in the process of advance training of education executives. It consists of pedagogical, information and communication technology of training.

Some scholars believe [10] that information and communication technology is the essence of the means of the realization of pedagogical, as well as educational and developmental goals. The effectiveness of any type of e-learning depends on four components: a) effective interaction between the instructor and the student over a distance between them, b) use of pedagogical techniques, c) effectiveness of the developed methodological materials and methods of their delivery, and d) effective feedback. In other words, the effectiveness of distance learning depends on the quality of teaching materials and the skills of instructors. Therefore, the pedagogical, content side of the organization of distance learning is of high priority.

Hence, the importance of conceptual pedagogical statements that serve as a basis of the entire distance learning process is obvious. They can be presented in brief as follows:

1. Independent cognitive activity of a student (learning, not teaching) is in the centre of education. 
2. Students' ability to gain knowledge independently, using different sources of information, various methods of cognition, to analyze information; opportunity to work with information when students' schedule allows.

3. Students' active cognition is not limited by gaining knowledge, but extends to its application to solving various problems of surrounding reality.

4. Implementation of innovative pedagogical techniques, appropriate to the peculiarities of e-learning, namely, cooperative learning, project-based learning, research and problem methods.

5. Active interaction with distance learning instructor-mentor, as well as with other partners, thus resolving the problem of socialization.

6. The system of control is to be systematic and be built on the basis of operative feedback (operative connection with the instructor or consultant at any time convenient for the student) and deferred control (testing).

It is worthwhile to note that the process of knowledge management is the basis of distance learning. The essence of this process can be defined as follows: while transmitting knowledge over a distance, the instructor processes and interprets it according to his/her personal experience. Students, in their turn, master information through the prism of their personal style of perception, interpretation, understanding, and memorizing. The instructor works out several ways of learning the models of knowledge representation, various methods of educational activity, structures information he/she has and provides its storage, filtration and transmission. In other words, we are talking about pedagogic design - a systems approach to training structure that allows to build a unique system based on educational goals, teaching materials and tools accessible for knowledge transmission.

The foundation for the formation of the term "pedagogical design" rose from its analog in a foreign educational practice - "instructional design" [8].

$\mathrm{O} . \mathrm{Yu}$. Uvarov defined pedagogical design as the "systematic use of knowledge (principles) of effective educational work (learning and teaching) in the process of designing, development, assessment, and use of training material" [12].

Every instructor chooses his/her unique technique of preparing for and conducting classes. Its purposefulness, theoretical and practical value of content, 
successful use and combination of different forms of the organization of cognition depend on the depth of the instructor's understanding of the goal of the course and its direction.

Instructor chooses by themselves the best way of its realization within certain multimedia material using personal computers by listeners, taking into account their age, psychological and individual features, initial level of PC literacy. The designing of the media support of a lesson, creation of its integrity by means of information and communication technology are a very difficult and time-consuming process aimed at reducing the amount of work in class in favor of independent learning and communication between students. Electronic means support lots of educational components, which are usually provided by direct communication between the instructor and students.

The creation of a poly-model environment by the instructor, which supports and considers the relations between objects, creation of conditions for the selection of the scheme of interaction of the student with training material, as well as of the way to complete a task, manipulate objects, interfere into processes, is the creation of new pedagogical tools, which are to give an opportunity to make classes more compact, to give additional time for cooperation with listeners, to gain knowledge independently or collectively, and to create interesting educational projects.

To create methodologically sound product, e.g., digital training material, the instructor has to use a creative approach and his/her personal pedagogic experience regarding the application of modern didactic methods in educational process.

The basis of psychological and pedagogical approach to pedagogical design planning and its further use to teach students consists of the following principles:

1. The principle of the distribution of training material. Digital educational resources can be divided into two groups: those that are in students' possession (local components) and those that are stored in the computers belonging to educational institution (network components). The information location mode requires some special conditions regarding the creation of and access to the resources. Local components consist of not only computerized information, but also printed editions, 
digital audio and video records. The characteristic feature of network components consists in easy controlled access. It can be used in educational process management.

2. The principle of interactivity of teaching material: interactivity is the most important characteristic feature of computer educational technology. It allows saving the benefits of traditional education in e-learning almost without any quality loss.

3. Principle of multimedia presentation of information: multimedia technology allows the combination of various media of information presentations, such as text, static and dynamic graphic, video and audio records, into one complex. It lets students become active participants of the educational process, as information output is subject to certain actions by the student.

The use of multimedia allows individual characteristics of information perception to be considering to the fullest extent. It is especially important during the indirect (computer-mediated) transfer of information from the instructor to students.

4. Principle of adapting to student's individual profile: modern educational methods and forms require the creation of certain psychological and pedagogical basis, as success and quality are impossible without it. The technological realization of psychological and pedagogical considerations is of special importance in the process of the development of quality educational resources.

The significance of the afore-mentioned principles consists in the fact that they form psychological, pedagogical, and methodological requirements to digital educational resources. Meeting such requirements increases the quality of the developed training material.

The modern educational paradigm built by means of computer educational means does not ground on the transfer of knowledge and skills that the student has already obtained, but on the formation of skills to gain necessary knowledge independently.

Student's self-instruction is actively used and is characterized by the form of communication with the instructor. This communication is mediated with interactive computer programs and audio-visual tools. 
Taking into account the afore-mentioned statements, we can specify the concept of "knowledge management".

Knowledge management theory provokes different opinions regarding the essence of the concept "knowledge" [6] and the essence of the process of knowledge management:

1. If knowledge is viewed as practical information, then knowledge management means forming, renewing, and using it systematically,

2. If knowledge is viewed as any word, fact, example, event, rule, hypothesis, or model, then knowledge management means formalizing and enabling the access to practical experience and knowledge; it becomes a component of training.

Both the subject and the object of knowledge management in e-learning require a more precise definition. The object of the research in the management theory is intangible assets, which consitute up to $50 \%$ of production companies investments (scientific research and developments, training, professional experience, etc.). In distance learning, intangible assets are presented by pedagogical knowledge and instructor's skills [11].

The creation of a digital training course is gaining importance under the conditions of distance training of educational executives. It ensures advanced training, using online-lessons (webinars) and provides a complex study of modern and relevant scientific issues in the sphere of education, science, pedagogical science, corresponding legal acts, domestic and foreign experience, and improvement of students' level of professional culture. Prominent among the objects of knowledge management are the following skills of the instructor teaching advanced training courses: building comprehensive online course package, reorganizing and designing training materials, guidelines, course of lectures, etc. Such intangible assets are based on professional knowledge [11]:

- $\quad$ informative knowledge ("know what"): professional teaching of a basic discipline, which is achieved by intensive training and certification; 
- $\quad$ practical knowledge/mastery ("know how"): convert "book study" into effective realization; use rules regarding definite discipline; solve real difficult problems;

- $\quad$ system understanding ("know why") includes will, motivation, and attitude for success.

- $\quad$ Thus, practical knowledge/mastery and system understanding are of great value in distance learning. A distance learning instructor, who is, at the same time, the author of the course and tutor, shall:

○ know how to solve practical tasks using theoretical knowledge;

○ be aware why it is solved in such a way; and

○ describe the corresponding plan of actions, present it in oral and graphic forms.

While defining the guidelines of knowledge management in a distance learning system, the main scientific approaches to this issue are to be mentioned [3], [4]: western resource-based approach (considers intellectual capital components as the important resource of company's development) and eastern approach (based on the mechanisms of the management of the process of organizational knowledge management and administration).

According to some scholars [11], the eastern (Japanese) approach [10] is the most accepted one in the context of pedagogical knowledge management. It is based on the concept of the fundamental heterogeneity of the two kinds of knowledge:

1. Structured (explicit) knowledge, which is generalized in theoretical and practical literature, as well as in the specifications of inventions, discoveries, and manuals of all kinds that regulate materials and other sources;

2. Unstructured (implicit/tacit) knowledge exists in a form of skills and is passed on from one employee to another through individual communication and teaching/learning.

Explicit pedagogical knowledge is the kind of knowledge that can be recorded, conveyed, and included into a database (for instance, a course of lectures, chrestomathies, study guides, and guidelines). 
Implicit pedagogical knowledge includes secrets of mastery, experience, creativity, and intuition. This type of knowledge is difficult to be formalized, recorded, written down, captured, and documented. However, the volume of the implicit knowledge reduces as the scholarly research includes more and more ideas and concepts, describes a model of educational process and teaching experience.

Taking into account the research conducted by Yu. P. Adler, Ye. A. Chernykh, and L. N. Ruliene [1, pp. $8-15]$, [11], it is necessary to note that the acquisition and implementation of knowledge in the context of educational process includes four stages:

1. Socialization is an informal transfer and exchange of informal knowledge (teaching techniques of, skills in, and approaches to solving educational and methodological problems). New unstructured pedagogical knowledge is gained in a form of tutorship and experience exchange among employees during methodological seminars, advanced training, and organizational activity games, as well as trainings, etc.;

2. Externalization is a conversion of unstructured knowledge into structured one. It is being achieved through printed reports, methodological guidelines, and study guides;

3. Combining is an acquisition of new knowledge on the basis of existing structured knowledge (generalization, development and rejection of knowledge acquired earlier and recorded in various sources): publication of scientific and pedagogical articles, writing and defending theses, comments on the Internet publications, participating in forums (the instructors' council on the Internet), etc.;

4. Internalization is a conversion of structured knowledge into unstructured one: the formation of skills and teaching techniques by means of studying and practical implementation of methods and techniques.

In the setting of global informatization, pedagogical knowledge and skills in a system of the advanced training of education executives can be presented in both Internet-societies and Internet-conferences, forums, methodological seminars, open online lessons (webinars), which facilitate their implementation. Our personal 
experience suggests that active discussions during online sessions (webinars) produce a bank of ideas and approaches to the problem, which is nothing but the structuralization of implicit knowledge. Therefore, webinars can be considered a knowledge management means, which ensures the development, storage, accumulation, and publication of the intangible assents of the pedagogical community.

Webinars enable the effective processing of information flow. Wellcoordinated work of its participants allows the completion of tasks impossible for one person. By means of webinars, it becomes possible not only to transfer knowledge and experience, but also to bring together its participant, to articulate an "expert opinion" regarding the creation of new products, and to reduce time for information search and standardization of procedures [5]. According to the above-mentioned, the Internet-communities, web-forums, and webinars are the best choice for finding new solutions for distance learning.

Knowledge management in distance learning during advanced training of education executives includes the development and publication of instructions for working in the system, recommendations of designers, tutors, and students. Instructions and recommendations are available at the network (on forums, Internetmagazines, blogs, etc.) and are printed as well. In such a way, a methodological bank of distance learning forms, which can be renewed, enriched, and updated on a regular basis.

Knowledge management in e-learning in the process of advanced training of education executives is based on understanding knowledge as a result of individual work, with explicit and implicit knowledge in its basis. Distance training includes:

- explicit knowledge transmission (development and hosting of educational resources. In other words, an author of the course presents documented and structured information, which is to become knowledge on the Internet); and

- implicit knowledge publication (guidelines, recommendations, error analysis, etc.; something that we read "between the lines", "notes on the margins"). 
The effectiveness of e-learning depends on the existence of structured (explicit) and unstructured (implicit) knowledge. Implicit knowledge is ultimately more valuable than explicit one.

Therefore, among the forms of storing and distributing implicit knowledge during advanced training, distance digital educational courses, Internet-lessons, methodological seminars (if their syllabi includes webinars) occupy prominent place. Webinars allow students to present their experience of professional activity, analysis of progress, author's methodology, etc. Nowadays, information systems, knowledge portals, etc. as forms of specialized databases (abstract, reference, expert) distribute and store necessary information and knowledge for researchers and practicing educators working within the system of advanced training of education executives in institutions of postgraduate pedagogical education.

The potential of information and communication technology for the sphere of education is especially significant in advanced pedagogical education. The implementation of the newest means and methods of teaching/learning enables the organization of an effective educational process under the conditions of distance advanced training (the most convenient for the students). It gives the opportunity to have a comprehensive training while remaining in service. At the same time, instructor's activity, directed to the use of digital educational resources, developed by the tutor independently or with the help of web-specialists, changes. This form of work consists in the development of the methodology of an individual session or an individual task for a student (group of students) using various techniques of distance learning. Thus, it can be argued that pedagogical design is a new technology in the design of educational process.

The basis of the educational process of advanced training of education executives, which is becoming a mediated communication with the instructor using interactive computer programs and audio-visuals, is formed by an innovative technology of explicit and implicit knowledge management.

"Instructor's" pedagogical design is the work he/she has to undertake to prepare for the use of information and communication technology in educational 
process. This activity can exist in two forms: creative (the development of author digital educational resources using corresponding technology and network tools) and adaptive (the use of digital educational resources developed by professionals or instructors).

Today in Ukraine the systems approach to the study of modern achievements in the field of pedagogical design is non-existent; in particular, the system of advanced pedagogical education lacks the professional training of specialists in this field, the requirements to the professional competence of instructors who know pedagogical design have not been articulated; teaching and methodical materials for such preparation are virtually not available.

The introduction of e-learning is a difficult multi-vector process, which needs considerable material, intellectual, financial resources and requires that a complex of legal, organizational, technological, methodological, and other problems be resolved. Further research in this area should deal with the analysis of the effectiveness of the implemented methodologies of the advanced training of education executives.

\section{References}

1. Adler Yu. P., Chernykh Ye. A. Znaniya i informatsiya - ne odno i to zhe [Knowledge and Information are not the Same Things]. Informatsyonnoe obshchestvo. 2001. No. 6. Pp. 8 - 15. (rus)

2. Bolshoy anglo-russkiy slovar [Unabridged English-Russian Vocabulary]. Ed. by I. R. Galperin, E. M. Mednikova. Moscow: Russkiy yazyk. 1987. Vol. 1. A M. 1038 p. (rus)

3. Golubkin V. N., Kalendzhyan S. O., Kleva L. P. Biznes-obrazovanie v protsesse upravleniya znaniyami [Business Education in the Process of Knowledge Management]. Biznes-Obrazovanie. 2006. No. 1 (20), 2006. Retrieved from: http://www.ou-link.ru/pub/2006_biz_obraz_2.htm. (rus)

4. Koulopoulos T. M., Frappaolo C. Upravlenie znaniyami [Smart Things to Know About, Knowledge Management]. Moscow: Eksmo, 2008. 218 p. (rus) 
5. Marinicheva M. Upravlenie znaniyami i tekhnologii [Knowledge Management and Technology]. Retrieved from: http://bigc.ru/publications/other/km/km and tech.php. (rus)

6. Milner B. Z. Upravlenie znaniyami: printsypy, metody, effektivnost [Knowledge Management: Principles, Methods, and Effectiveness]. Retrieved from: http://www.koism.rags.ru/publ/articles/26.php. (rus)

7. Nonaka I., Takeuchi H. Kompaniya - sozdatel znaniya. Zarozhdenie i razvitie innovatsiy v yaponskikh firmakh [The Knowledge-Creating Company: How Japanese Companies Create the Dynamics of Innovation]. Transl. from English. Moscow: Olimp-Biznes, 2003. 384 p. (rus)

8. Definitions of Instructional Design. Adapted from "Training and Instructional Design". Applied Research Laboratory, Penn State University. Retrieved from: http://www.umich.edu/ ed626/define.html. (eng)

9. Podkovyrova V. N. Osnovy pedagogicheskogo dizayna [Foundations of Pedagogical Design]. Retrieved from: http://files.schoolcollection.edu.ru/dlrstore/cd9ae8e0-6880-4ee5-9e6f-f46b7629d00b/podkovirovadezign.pdf. (rus)

10. Polat Ye. S., Petrov A. Ye. Distantsionnoe obuchenie: kakim yemu byt? [Distance Learning: What should it Look like?] Retrieved from: http://distant.ioso.ru/library/publication/artped.htm. (rus)

11. Ruliene L. N. Upravlenie znaniyami $\mathrm{v}$ informatsionnom obshchestve [Knowledge Management in Information Society] Retrieved from: http://ruliene.bsu.ru/wp-content/uploads/ruliene1.pdf. (rus)

12. Uvarov A. Yu. Pedagogicheskiy dizayn [Pedagogical Design]. Informatika: attachment to the magazine Pervoe Sentiabria. Kyiv, 2003. August 8 15. No. 30. Pp. 2 - 31. (rus)

Ляхоцька Л. Л. Підвищення кваліфікації керівних кадрів освіти: технології дистанційного навчання

У статті розглянуто проблеми підготовки керівних кадрів освіти в умовах інформатизації підвищення кваліфікації, яка передбачає розробку та 
впровадження нових моделей навчання 3 використанням інформаційних та телекомунікаційних технологій. Звернено увагу на те, що готовність керівника навчального закладу до використання таких технологій постає важливою умовою переходу до особистісно зорієнтованого навчання, яке відповідає вимогам розвитку інформаційного суспільства. Розкрито механізми підготовки викладачів навчальних закладів післядипломної педагогічної освіти до використання в навчальному процесі підвищення кваліфікації методики управління знаннями, в основі якої лежить педагогічний дизайн, що дає можливість організувати в підвищенні кваліфікації ефективний навчальний процес у найбільш прийнятній для слухачів формі- дистанційній, яка забезпечує можливість повноцінного навчання без необхідності вносити значні зміни в поточну діяльність.

Ключові слова: управління знаннями, педагогічний дизайн, дистанційне навчання, інноваційні педагогічні технології, підвищення кваліфікації керівних кадрів освіти.

\section{Ляхоцкая Л.Л. Повышение квалификации руководящих кадров} образования: технологии дистанционного образования

В статье рассматриваются проблемы подготовки руководящих кадров образования в условиях информатизации повышения квалификации, предполагающих разработку и внедрение новых моделей обучения с использованием информационных и телекоммуникационных технологий. Обращается внимание на то, что готовность руководителя учебного заведения к использованию таких технологий выступает важным условием перехода к личностно ориентированному обучению, отвечающему требованиям развития информационного общества. Раскрываются механизмы подготовки преподавателей учебных заведений последипломного педагогического образования, направленные на использование в учебном процессе повышения квалификации методики управления знаниями. В основе этой методикипедагогический дизайн, который дает возможность организовать эффективный учебный процесс в наиболее приемлемой для слушателей форме - 
дистанционной, обеспечивающей возможность полноценного обучения без необходимости внесения значительных изменений в текущую деятельность.

Ключевые слова: управление знаниями, педагогический дизайн, дистанционное обучение, инновационные педагогические технологии, повышение квалификации руководящих кадров образования.

\section{Liakhotska L. L. Advanced Training of Education Executives: Distance}

\section{Learning Techniques}

The article addresses the issues of the advanced training of education executives under the conditions of its informatization, which entails the development and introduction of new models of instruction using information and telecommunication technology. It is emphasized that the willingness of the senior executive of an educational establishment to use information and telecommunication technology is an important precondition for the shift to the personality-oriented training, which is the requirement of the development of the information society. The article also presents the mechanisms of training professors teaching in continuous education programs to use knowledge management methods, which are based on the pedagogical design. This helps organize an effective educational process in the most acceptable form - distance learning, which ensures the value education of executives who remain in service. Among the forms of same, the author analyzes distance e-courses, online learning, methodological seminars conducted as webinars, etc.

The article states that the concept of pedagogical design is lacking in modern Ukrainian education research; the requirements to the professional competence and understanding of the concept "pedagogical design" are yet to be defined; there are no programs available to train education practitioners in this field.

Key words: knowledge management, pedagogical design, distance learning, innovative pedagogical techniques, advanced training of education executives.

The article was received by the Editorial Office on 31.10.2013

The article was put into print on 28.02.2014 Peer review: Khrykov Ye. M., Doctor of Pedagogical Sciences, Professor 